\title{
Changing Parties, Changing Partisans \\ The Personalization of Partisan Attachments in Western Europe
}

\begin{abstract}
This paper investigates the effects of the deep transformations undergone by West European class-mass parties on their relationship with the electorate. Attention is devoted to the changing nature of individuals' partisan attachments, which we hypothesize to have shifted from a reflection of previous social and ideological identities to the result of individual attitudes towards more visible partisan objects. The main objective of this analysis is to show the foremost part played by voters' attitudes towards one of these 'objects' -party leaders- in determining psychological attachments with the parties. Our analysis concentrates on the two main cleavage-based parties in Britain, Germany, Italy, and the Netherlands in the period between 1990 and the most recent election. The empirical analysis shows the constantly declining ability of social identities (class and religious) to predict individual feelings of partisan attachment, as well as the correspondingly growing part played by voters' attitudes towards party leaders. The discussion of our findings points to the crucial role that political psychology can play in our understanding of democratic elections' outcomes.
\end{abstract}

Keywords: attitudes, comparative politics, partisanship, party leaders, party transformation, personalization of politics 


\section{Introduction}

Until recently the study of political attitudes and behavior has been rather 'situationist' in character, and hitherto dominated by approaches emphasizing the role of macro-social factors such as class, region and religion ('t Hart, 2009). However, the decline of traditional cleavage structures and their ability to shape the political competition (Franklin et al., 1992) has made such an approach progressively less useful in understanding the relationship between the main political actors (the parties) and contemporary reasoning voters (Popkin, 1991).

The widespread erosion of traditional socio-political alignments in advanced industrial democracies (Dalton and Wattenberg, 2000) has in fact resulted in a progressive individualization of vote choices, which involves "a shift away from a style of electoral decision-making based on social group and/or party cues toward a more individualized and inwardly oriented style of political choice”, mainly based on "policy preferences, performance judgments, or candidate images” (Dalton, 1996: 346). This occurrence has made necessary for class-mass parties to reshape their appeal in order to extend the electoral basin beyond the socio-ideological cleavages to which they usually referred (Mair et al., 2004). This process of transformation, already previewed by Downs (1957) and further detailed by Kirchheimer (1966), found its symbolical culmination in the fall of the Berlin Wall in 1989 - a turning point after which parties could not be thought anymore as representing "bodies of particular principle”, but rather as "vote maximizing agents without any real ideologies of their own" (Daalder, 2002: 52). As a result, contemporary catch-all parties have become de-ideological in nature, highly flexible in their issue programmes (Farrell and Webb, 2000), and tend to base increasingly their election profiles on features more engaging to voters - such as the leadership factor (Evans and Andersen, 2005; Farrell, 1996). 
The emergence of television as main source of political information for a vast majority of Western electorates has been crucial in emphasizing the role of political leaders at the expense of parties, making the latter "more dependent in their communications with voters on the essentially visual and personality-based medium of television” (Mughan, 2000: 129). Although any single answer to the question of how media shape politics can only be a partial one (Couldry, 2009) it is hard to deny that television-based campaigning has progressively accentuated personality factors at the expense of more substantive programmatic goals (Campus, 2010). In such context, leaders may well find themselves better able to shape the electoral appeal of their own parties (Curtice, 2003).

In this article, we will attempt to assess the effects of these transformations on the parties' relationship with their supporters. In particular, our attention will be devoted to the changing nature and content of individuals' feelings of psychological attachment with political parties. In spite of the numerous contestations targeted to the concept at both theoretical and empirical level (Budge et al., 1976), we remain convinced of the enduring importance of partisanship in cross-national research (this conviction being shared with, among others: Richardson, 1991; Holmberg, 1994; Berglund et al., 2005; Schmitt, 2009). As long as party-based democracies are around, “people’s different relationships with the major actors - the parties - must be conceptualized and measured” (Holmberg, 2007: 566).

There are many routes by which voters may come to think of themselves as 'partisans' (Bartle and Bellucci, 2009). In its classic formulation set forth in The American Voter (Campbell et al., 1960) partisanship is conceived as a long-term affective orientation to a political party, which is rooted in early socialization and based on an objective location in the social structure. Nowadays the political relevance of traditional cleavage structures is markedly smaller than it was when the concept of party identification was first conceived (Oskarson, 2005). However, we agree with Berglund et al. (2005) that "party identification 
should not necessarily decline in the slipstream of the decline of the relationship between social structure and party system” (107). Indeed, in recent years a new understanding of the concept in terms of modern attitude theory has emerged (Weisberg and Greene, 2003). In this perspective partisanship is interpreted as a "psychological tendency that is expressed by evaluating a particular entity with some degree of favor or disfavor” (Eagly \& Chaiken, 1993: 1). At the outset of this favorable (or unfavorable) partisan attitudes there are a number of factors more strictly political and 'dispositionist' in character (Houghton, 2009) such as issue proximity, past performance, or favorable leader evaluations (Bartle and Bellucci, 2009: 201).

Our analysis moves from the assumption that, like all political attitudes, partisanship is responsive to the set of alternatives available (i.e., attitude objects) in a political system at a particular point in time (Crewe, 1976). Previous studies have indeed demonstrated how specific party characteristics contribute to distinctive types of partisanship (Richardson, 1991). Therefore, the erosion traditional social cleavages and the resulting transformation of former class-mass parties into catch-all lead us to hypothesize that partisan loyalties have shifted accordingly from a mere reflection of previous social and ideological identities (as postulated by the Michigan conception of party identification) to the result of individual attitudes towards more visible partisan objects, such as their leaders (Converse, 1995).

The relevance of our research question is twofold. First, it is electorally relevant. Contemporary partisans share with their traditional counterparts a strong propensity to vote for the party they identify (Berglund et al., 2005). In this sense, we deem important to understand the psychological dynamics underlying the process by which they come to feel attached to a specific political party. At the same time, our findings can be relevant from a methodological point of view. By showing the foremost effect exerted by individual attitudes as main drivers of one's partisanship, we hint at the crucial role that political psychology can 
play in answering the often neglected how question (Houghton, 2009) of voting behavior research.

The choice of cases under analysis is based on the Most Different Systems Design. We have chosen four established parliamentary democracies in Western Europe - Britain, Germany, Italy, and the Netherlands - connoted by sharp differences in terms of electoral system, size of party system and structure of political competition. Our attention will be concentrated on the main representatives of cleavage-based parties (Lipset and Rokkan, 1967) in each of these countries ${ }^{1}$. The time period under analysis spans the two decades between the fall of the Berlin Wall and the most recent national election for which National Election Study data is available ${ }^{2}$. By means of multinomial logistic regression, we show the constantly declining ability of 'identities' (e.g., class and religious) to predict individual feelings of partisan attachment, as well as the correspondingly growing part played by voters' attitudes towards issues, performance evaluation, and party leaders - the latter having become nowadays of crucial relevance in each country under analysis. Evidence about the direction of the causal flow (e.g., positive attitudes towards leaders cause feelings of attachment to parties) is also presented.

The article proceeds as follows: we first review the relevant literature on partisanship, in order to formulate our research hypotheses (Section 2); these are tested against the four cases at hand (rationale for the cases chosen in Section 3) at both bivariate (Section 4) and multivariate level (Section 5). Finally, the results of the empirical analysis are discussed along with their relevance and implications for the field of political psychology (Section 6).

\footnotetext{
${ }^{1}$ We decided to concentrate on (former) class-mass parties alone as the process outlined in this paper (e.g., decline of ideologies and cleavage-based politics, resulting transformations at the party level) can be thought to exert its effects mainly on the relationship between voters and this kind of parties.

${ }^{2}$ Presumably, the process we are hypothesizing started way before 1990 due to longer-term trends of modernization and secularization among Western societies. However, we chose to focus on the last two decades in virtue of the obvious acceleration ignited to the process of party transformation by the fall of Berlin Wall, as well as for reasons of data availability (the first Italian National Election Study has in fact been conducted in 1990).
} 


\section{Two Conceptions of Partisanship: Identity and Attitudinal Approaches}

Different routes can lead an individual to think of himself as 'partisan'. Yet, there are essentially two explanations of this tendency in the literature: namely, the identity and attitudinal approaches (Bartle and Bellucci, 2009). The identity approach describes party identification as "the individual's affective orientation to an important group-object in his environment” (Campbell et al., 1960: 121). This sense of 'we feeling' can be focused either on primary (e.g., race, religion, social class) or secondary groups (e.g., the parties themselves), and it is mainly product of early socialization. The analytical usefulness of the concept lies in its relative stability and distance from the vote choice. Party identification is in fact conceived as an unmoved mover: that is, a pre-political attitude (hence supposedly immune from political and economic short-term influences), which is nonetheless able to shape the individuals' political world-view in a way that accords with their partisan orientation. On these bases, partisanship is thought to be cause - but not consequence - of less stable attitudes and opinions about political objects (e.g., political events, issues and candidates). To put it sharply, the identity approach sees partisanship as "an exogenous variable affecting politics but not being affected by politics” (Holmberg, 2007: 563).

Reciprocal causation, however, can represent a problem in this context. As it has been observed, "[p]arty identification is shaping behaviors, attitudes, and perceptions at the same time as it is shaped by attitudes and perceptions" (ibid., 562). Claims of this sort have led to an intrinsically different view of partisanship - simply, a positive/negative disposition toward an attitude object (Converse, 1995). Already the authors of The American Voter spoke about the role of attitudes as "potential agents of change in the individual's basic partisan orientation” (Campbell et al., 1960: 135). In the 1970s a group of 'revisionists' (Fiorina, 2002) openly questioned the non-political definition of party identification set forth by Campbell and colleagues, putting emphasis on the importance of cognitive factors as 
formative aspects behind individuals’ partisan alignments. A number of studies explored in detail the dynamic relationship between partisan affiliations and short-term attitudes, demonstrating the absence of a clear causal sequence from the former to the latter (Page and Jones, 1979; Fiorina, 1981).

In drawing a sharp distinction between these two approaches, we do not imply that one perspective is correct at the expense of the other. Following Rosema (2006), we rather believe that

"partisanship may be conceptualized in terms of identification as well as evaluation. Which conceptualization one prefers will depend on how one views political parties (as groups to which voters may belong, or as organizations that voters may like or dislike)” (Rosema, 2006: 470).

Like all political attitudes, partisanship is supposedly responsive to the particular set of political alternatives available in the political system (Crewe, 1976). Therefore, the nature and shape of partisan ties must be influenced, to at least some extent, by the specific characteristics of political parties themselves (Richardson, 1991). Old cleavage parties were characterized by a tight link with their respective social milieu (Lipset and Rokkan, 1967). In this sense, they could be conceived as groups to which partisans 'belonged' (Butler and Stokes, 1969; Thomassen, 1976; Parisi and Pasquino, 1977). However, the process of transformation undergone by Western class-mass parties in the last decades has led these parties to a progressive de-attachment from the socio-ideological cleavages to which they usually referred (Mair et al., 2004). According to the original Michigan conception of party identification, favorable attitudes towards partisan objects are caused by long-term loyalties based on primary group memberships. But if it is true (as we expect) that contemporary 
partisanship is not anymore a consequence of socialization forces, then we can assume that individual feelings of closeness to parties are caused exactly by those attitudes that the identity approach conceive as consequences of pre-existing identifications. Based on this assumption, we hypothesize that the process of party change has transformed the nature of partisanship from a reflection of previous social identities to the product of individual attitudes towards parties and partisan objects.

Among the possible sources of favorable attitudes towards the parties, the literature assigns a crucial place to issue preferences. The standard model of rational decision-making based on issues, as applied to the study of voting behavior, is the spatial model developed by Anthony Downs (1957). Voters and parties are placed on a left-right continuum - a "superissue which summarizes the programmes of opposing groups” (Inglehart and Klingemann, 1976: 244). In such model, issue proximity is responsible for the promotion of positive (or negative) attitudes towards each of the parties (Budge et al., 1976), and eventually determines voters' choices. Another important source of attitudes towards parties is represented by valence issues - that is, instances in which there is a wide consensus over what goals are desirable, but there is conflict over which party is best at delivering them (Stokes, 1963). Attitudes can derive in this case by either retrospective evaluations of party performance (Fiorina, 1981) or prospective competence assessments (Bellucci, 2006).

Attitudes towards parties can also originate from voters' evaluations of other objects strongly associated with the image of parties themselves, such as their leaders (Page and Jones, 1979). Already in 1968, V. O. Key anticipated a later, cognitive view of partisanship hypothesizing that "[l]ike or dislike of a political personality...bring shifts in party identification” (Key, 1968; quoted in Clarke et al., 2004). According to this interpretation, partisanship is moved by individual attitudes toward the party as 'personified' by the leader, 
and therefore feelings of closeness should be brought back to the party 'in the form of its leader' (Barisione, 2009).

Indeed, we contend that this interpretation is ever more appropriate in the light of the progressive personalization of politics in Western democracies (McAllister, 2007). In the last decades, there is little doubt that party leaders have increasingly gained importance to both political communication and electoral competition vis-à-vis their parties in almost every Western democracy. Impressionistic evidence of this trend include the substitution of leader images for party symbols during election campaigns (McAllister, 1996), the media's increasing propensity to mention candidates rather than the parties they belong to (Dalton et al., 2000), and the tendency to portray executives in a personalized fashion - these being routinely labeled after the name of their leaders (Bean and Mughan, 1989).

Among the consequences of the personalization of politics, it must be highlighted the central role gained by political leaders within voters' political reasoning. Empirical research in political cognition shows that the most diffuse political schema among contemporary voters is the one based on leaders (Miller et al., 1986; Sullivan et al., 1990). The reason is clear: ideologies, issues, and performance assessments are inherently political, and thus require more sophistication to understand (Pierce, 1993). Party leaders, on the contrary, can be easily evaluated using inferential strategies of person perception that are constantly employed in everyday life (Kinder, 1986; Rahn et al., 1990). Relying on implicit personality theory, individuals are therefore able to determine new judgments based on an overall character assessment when more concrete cognitions are required (Greene, 2001). On these bases, and in the light of the progressive personalization of politics, we hypothesize that among all possible sources of favorable attitudes towards the parties, those related to the party leader have become the strongest determinant of partisanship at the individual level. 


\section{Britain, Germany, Italy and the Netherlands: Reasons of a Comparison}

Our research hypotheses will be tested through a comparative analysis of four established parliamentary democracies in Western Europe: Britain, Germany, Italy, and the Netherlands. The choice of these four countries (connoted by sharp differences in terms of electoral system, size of party system and structure of political competition) highlights many of the crucial variations in the structure of democratic politics, thus allowing for a broader based assessment of our research hypotheses.

Italy. There are strong reasons to believe that our expectations can be by and large fulfilled within the Italian case. In the First Italian Republic (1946-1993), the stability of party identifications was especially accentuated by the tight link between primary groups and the main parties of that time (e.g., DC and PCI). In such context, partisanship was regarded as "a form of social embeddedness, a closure in distinctive and separate political sub-cultures and enclaves which Italian mass parties were able to bring about” (Bellucci, 2007: 58). Although the identity approach did provide a valuable explanation of the ties between voters and parties in pre-1994 Italy, the same approach does not seem appropriate for an account of the nature of mass partisanship in the Second Republic. Italy is in fact the only country among established industrial democracies to have recently experienced the simultaneous dissolution of almost all main parties from an election (1992) to another (1994). With the fall of Berlin Wall in 1989, the Cold War pattern that had marked Italian politics since the end of WW2 suddenly lost its historical meaning. In such context the old partitocrazia, already weakened by an erosion of the stable social cleavages on which it was based and eventually wiped out by Tangentopoli scandals, left the way to a new typology of post-ideological, highly 'personalistic' parties (Gunther and Diamond, 2003) - well exemplified by the sudden emergence of Silvio Berlusconi’s Forza Italia. 
Obviously, one should note that such abrupt pattern of party system transformation is definitely uncommon in the Western experience. In the wide majority of established European democracies, political parties did undergo a long, and at times hard, process of adaptation to the new context (i.e., widespread erosion of social cleavages, fall of ideologies, mediatization and personalization of politics) but by no means disappeared. It is for this reason that we decided to compare Italy with the British, Dutch and German cases. These countries are in fact marked by sharp differences vis-à-vis Italy in the developmental trajectory of their party systems (i.e., adaptation rather than change). If our research hypotheses were to be vindicated also against these three cases, this would rule out the uniqueness of the Italian experience (due to the party system breakdown of early 1990s) and boost our confidence in the role of systemic party transformation as causal determinant of the changing nature of partisan attachments.

The period under analysis begins in the aftermath of the Berlin Wall fall and covers the last two decades. Our interest in this particular time frame relates to (a) the peculiar ways in which personalization have replaced socio-ideological aspects of the political competition and (b) the interesting patterns of aggregate partisanship in each of these countries. Let us briefly review these points in turn.

Britain. Due to its historical legacy, Britain has long been considered to exemplify the archetypical class-based party system. In their pioneering study of voting behavior in Britain, Butler and Stokes (1969) depicted the British electorate as two large and stable blocs, with working-class voters on the Labour side, and middle-class on the Conservative one. To the progressive class dealignment of the 1970s (Crewe et al., 1977), both parties responded by employing brand-new catch-all electoral strategies. The increasing visibility of leaders within parties' communication with voters became all the most obvious since the Thatcher's years. Yet the best example of personalization among British parties is probably that of the New 
Labour. Under Tony Blair, the party cast off much of its ideological baggage (including the historic commitment to the public ownership of major industries) and transformed into an “exemplar of the modern electoral-professional competitor" (Webb, 2004: 44). From an organizational point of view, both Labour and Conservatives are nowadays denoted by extremely high levels of leadership autonomy and a thoroughly professionalized approach to political marketing (ibid.) that results in ever more personalized campaign strategies (Denver, 2007).

Germany. There are probably few words able to characterize better the politics of the Federal Republic of Germany than Parteienstaat and Kanzelerdemokratie. The first connotes the crucial role of political parties in the constitutional setting, while the second refers to the dominant figure of the Chancellor in the German system of governance (Saalfeld, 2000). After a long period of balance between the two, the last decades have witnessed a marked decline in the public image of political parties (Arzheimer, 2006) and a correspondingly growing exposure of the Chancellors (as well as that of individual candidates to the chancellorship) at the expense of their parties, especially during electoral campaigns. Although German campaigns have always been centered on candidates to some extent, it is only in the 1990s that the notion of personalization is, for the first time, discussed at length (Brettschneider and Gabriel, 2002). The charismatic figure of Helmut Kohl has been crucial in this respect, and his successful endurance on the political scene led ultimately his contenders and successors to follow suit. This was especially evident in the 2002 campaign, which large parties focused "almost exclusively" on their chancellor-candidates (Poguntke, 2005). The increasingly central role of the personality features of political leaders on their parties’ appeal is further corroborated by analyses of party structures, which testify of an unambiguous adoption of leader-centered electoral strategies on the behalf of the major German parties (Gunther and Diamond, 2003). 
The Netherlands. Contrary to the aforementioned cases, the Netherlands are hardly a case in point with respect to personalization. The Dutch civil society has long been founded on pillars, and virtually all areas of social life, including politics, were organized along the principles of class and religion (Andeweg and Irwin, 2003). Accordingly, the voters' relationship with parties was based on their belonging to the pillars, thus leaving little room for leading politicians' personality to affect their political attitudes and behavior (Irwin and van Holsteyn, 1989). However, the erosion of pillars and the resulting deterioration of traditional bonds between parties and voters have led also Dutch parties to reshape their appeal on increasingly volatile voters by highlighting "the qualities of individual politicians”, and most notably the "managerial skills of their prime ministerial candidates" (Fiers and Krouwel, 2005: 151). A critical step towards the personalization of Dutch politics is represented by the 2002 election, which saw the entrance of Pim Fortuyn on the political scene. His flamboyant rhetoric gained him an unprecedented attention in the media (Kleinnijenhuis et al., 2003). Fortuyn can be credited with changing the Dutch political landscape to a substantial extent, and in particular the way in which politics is presented to the public. Nowadays, it is common for Dutch campaigns to be depicted as horse races between the major parties' leaders (Fiers and Krouwel, 2005). Correspondingly, party structures have eventually converged around a small group of party leaders as key decision-makers within the party (Andeweg, 2000).

<--- Figure 1 about here --->

Along with the peculiar patterns of personalization in their political systems, our interest in these four countries is also related to the interesting patterns of aggregate partisanship that are observed in the last two decades (see Figure 1). Against an international 
trend of partisan dealignment (Dalton, 2000), we find signs of substantial stability since the early 1990s in the Netherlands, and even a significant increase in Germany since the 2000s. The case of Italy is slightly more complex: there is a steady downward movement, began in the mid-1980s because of the growing disaffection with parties, and culminated with the fall of the First Republic. After a peak in 1996, probably due to the widespread enthusiasm with the new political experience, the figure gets progressively down to roughly 50 percent. Although the trend line speaks almost unequivocally of a constant erosion of partisan ties, we must also note the major restructuration undergone by the Italian party system in both early1990s and late-2000s - an occurrence that makes us indeed surprised of the substantial hold in the figure relative to aggregate partisanship. With respect to Britain, after a relatively long period of stability we observe a steady decline in the last decade (minus 10 percentage points in the period 1997-2005). Nonetheless, Figure 1 highlights that in 2005 four Britons out of five declare to feel close to one of the parties - this proportion being the highest amongst the four countries under analysis.

It would thus seem that partisanship has remained somehow valuable to these countries' electorates, and especially in the most recent decades. Bearing this in mind, we now turn to the empirical section of our analysis.

\section{Data and Methods}

In the empirical analysis, we will assess the determinants of individual partisanship with respect to the two main cleavage-based parties in each country in the period between 1990 and the most recent national election for which National Election Study data is available (for study descriptions, see Appendix A). The parties under analysis are thus Labour and Conservatives for the British case, SPD and CDU for the German case, PvdA and CDA for the Dutch case. The abrupt changes in the Italian party system occurred in the early 1990s 
have led us to a slightly more difficult process of case selection. Eventually, we decided to base our choice on the criterion of electoral relevance. With respect to the socialist family, we therefore chose the Communist Party (PCI) along with its major heirs (e.g., Partito Democratico della Sinistra, Democratici di Sinistra, Partito Democratico), while on the righthand of the political spectrum, we picked Silvio Berlusconi's Forza Italia (since 2008: Popolo delle Libertà) as follower of the Christian Democracy’s (DC) electoral tradition.

The dependent variable of our analysis relies on the root question of party identification battery in each survey. One notes that question wording is hardly comparable throughout countries (see Appendix B); however, nontrivial semantic similarities are found between the ways in which respondents are asked about their attachment to parties ('leaning towards' in Germany, 'feeling closer to' in Italy, 'being an adherent of' in the Netherlands, 'thinking of themselves as' in Britain). Furthermore, question wording has been kept constant in each national survey, thus allowing for safe intra-country comparison. According to Dalton (2010), this question sacrifices "the notion of long-term partisan identity for a feeling of closeness to a party", but at the same time taps "affinity to a party separate from the vote, and it can be used in systems with diverse party traditions” (159).

The choice to stick to the directional component of partisanship alone (Holmberg, 1994) is based on the very aim of this research - that is, understanding the reason why respondents "select a response that indicated they 'think of themselves as' X or Y” (Bartle and Bellucci, 2009: 201) in spite of the transient shifts to which the strength component is often subject (Miller, 1991). We have thus generated a number of dichotomous variables one per party under analysis - coding ' 1 ' respondents declaring to feel close to that specific party and '0' all others.

The independent variables included in the analysis correspond to the indicators that are supposed to tap both social and attitudinal partisanship. As to the former, we include the 
respondent's frequency of church attendance (religious identity), subjective social class and trade union membership (class identity). We also control for standard socio-demographic variables (gender, age, and educational level). All variable codings are reported in Appendix C. For what concerns the attitudinal dimensions of partisanship, our analysis include indicators related to issue proximity (operationalized as the respondents' placement on a leftright scale ranging from '0-left' to '10-right'), party leader evaluations (thermometer scores on a scale from ' 0 ' to ' 10 '), and retrospective economic evaluations (respondents' perception of the national economic situation in the last year, ranging from a value of ' 0 ' when very negative to a value of ' 10 ' if very positive).

A first hint of the growing correspondence between individual respondents' evaluation of party leaders and their feelings of closeness to parties comes from the point-biserial correlation coefficients ${ }^{3}$ of these two variables as reported in Table 1.

<--- Table 1 about here --->

With respect to the magnitude of the coefficients, the table shows a substantial increase throughout time. Admittedly, only two parties (SPD and Italian Centre-Right) feature a monotonic increase of the coefficients' size. However, if one observes the mean values of the correlation coefficients relative to each decade, the increasing correspondence between partisanship and party leader evaluation emerges more clearly. With the only exception of British Conservatives, the relationship between party leader evaluations and partisanship is in fact stronger in the 2000s than it was in the 1990s for every other party under analysis.

To be sure, correlation does not prove causation, and even if we have theoretical reasons - at least, for the cases at hand - to believe that the causal sequence between voters'

\footnotetext{
${ }^{3}$ The point-biserial correlation coefficient is a special case of Pearson in which one variable (either dependent or independent) is quantitative and the other variable is dichotomous (Howell, 2009).
} 
attitudes toward party leaders and partisanship runs from the former to the latter, we still need to rule out other potential explanations. To this purpose, a number of multivariate analyses are in order.

The empirical analysis that follows consists in three steps. In the first part, we assess the ability of identity items to explain individual feelings of attachment to each of the parties under analysis. In our view the causal role of attitudes as determinants of alignment with parties can be illustrated, albeit only indirectly, by highlighting the manifest decline in terms of explanatory power on the behalf of identity items. If (more or less favorable) attitudes are to be interpreted as a consequence of previous party identifications, the latter must be based on pre-existing group identities. However, a clear lack of explanatory power by identity items - that is, a substantial absence of long-term social ties between parties and partisans represents, in our opinion, a convincing evidence of the independent role of attitudes as drivers of partisan alignments. This part of the analysis is aimed at showing that, consistently with our preliminary hypothesis, partisan loyalties have shifted from a mere reflection of previous social and ideological identities to the result of individual attitudes towards more visible partisan objects.

In the second part, we compare the relative strength of attitudinal items as statistical predictors of partisanship. In doing so, we show the growing impact of leader evaluations as opposed to other potential sources of attitudes (e.g., issue proximity, performance evaluations). Once ascertained the primacy of leader evaluations, we finally concentrate on the direction of the relationship between attitudes towards party leaders and individual feelings of attachment to parties. Using Granger's concept of causality (which assumes that cause precedes effect) we demonstrate that leader evaluations at $t_{1}$ are much more strongly related to partisanship at $t_{2}$ than partisanship at $t_{1}$ is to leader evaluations at $t_{2}-$ thus providing 
substantial confirmation of the causal link hypothesized (e.g., from favorable party leader evaluations to partisanship).

\section{Findings}

In order to assess the enduring validity of the identity-based explanation of partisanship, we have run thirty-six logistic regression models (one for each party/year under analysis). In every instance, the dependent variable is a dummy coding ' 1 ' the respondents identified with the party under analysis, and ' 0 ' apartisans as well as identifiers with parties other than the one under scrutiny. We include as independent variables the indicators that are supposed to tap both social (union membership, subjective social class $^{4}$ ) and religious (frequency of church attendance ${ }^{5}$ ) identities, plus the standard socio-demographic controls (gender, age, educational level). Table 2 presents the variance explained (Nagelkerke's Rsquared) in the dependent variable by each of these models.

\section{<--- Table 2 about here --->}

The key finding that emerges from the table is an overall decline of identity items' ability to explain feelings of partisan attachment. Not all parties present a monotonic downwards development. Indeed, half of the parties under analysis (those from Italy and the Netherlands) do. With respect to the others, the movement looks either curvilinear (British Consevatives, German CDU) or purely trendless (British Labour, German SPD). Yet if we concentrate on the last column of the table, the overall trend appears rather more uniform. This column features the slope $(b)$ of the line interpolating the values presented in the table

\footnotetext{
${ }^{4}$ Not available in the German datasets.

${ }^{5}$ This variable is not included in the analysis of British parties (for a discussion of Britain's uni-dimensional cleavage structure, see: Oskarson, 2005).
} 
for each party, and it is obtained by regressing the year of the survey on the corresponding value of the R-squared. In essence, it tells us the overall direction of the trend, which is negative in six out of eight cases and positive in two (British Conservatives, German CDU). Even more interesting to our purposes is to observe that each row (i.e., party) features the lowest value of the R-squared in the last time-point of the series, and that this lies below the critical threshold of .10 in six cases out of eight, and only slightly above in the remaining two (British Conservatives=.12; Dutch CDA=.17).

Based on the evidences presented, it would seem that the changing nature and content of partisan alignments is a widespread phenomenon in our four democracies. On the whole, this is connoted by a declining ability of identity items to explain partisanship. In the following step of the analysis, we will attempt to assess the relative power of various attitude forces in explaining partisan ties at the individual level, in order to verify whether - in accordance with our core research hypothesis - attitudes towards the party leader have actually become the strongest predictor of partisanship.

To compare the relative ability of attitude items to explain feelings of closeness to the main two parties in each country, we use multinomial logistic regression analysis. We have run eighteen models (one per country/year). Partisans of centre-right parties are coded ' 1 ' whereas respondents close to centre-left parties are coded ' 0 ' (the latter stand as reference category). Supporters of other parties and apartisans are coded '2' (contrast with the reference category is not shown). We include as predictors the batteries of identity items and sociodemographic controls previously employed plus a battery of attitudinal items (left-right self placement; retrospective economic evaluation; evaluations of both party leaders ${ }^{6}$ ). Table 3 shows the unstandardized regression estimates $(b)$. To our purposes, is worth noting that all

\footnotetext{
${ }^{6}$ The simultaneous inclusion of respondents' evaluations of both leaders in the model rests on the idea that candidate assessments are comparative in nature (Rahn et al., 1990; Sullivan et al., 1990). In the wide majority of cases under scrutiny, the leaders of the two main parties are also the 'natural' candidates to the country's premiership.
} 
coefficients relative to attitude items are comparable in magnitude (all variables are scaled on a range between ' 0 ' and ' 10 ').

<--- Table 3 around here --->

To begin with, an overall assessment of the model fit is in order. Looking at the Nagelkerke's coefficient of multiple determination, we observe a substantial uniformity in the various models' explanatory power [Britain: .57 $<\mathrm{R}^{2}<.68$; Germany: .48 $<\mathrm{R}^{2}<.62$; Italy: $.46<\mathrm{R}^{2}<.56$; The Netherlands: $.41<\mathrm{R}^{2}<.50$ ]. This finding is of interest, since it demonstrates that to a decline in the predictive power of identity items does not correspond a parallel decrease on the behalf of the composite model - thus confirming the validity of our preliminary assumption (see above).

Moving to the single attitudinal predictors of partisanship, we first note a differentiated impact of left-right position and leader evaluations, on the one hand, and retrospective economic evaluations, on the other hand. The former are in fact statistically significant in each model, while the latter do not seem to play a comparably strong part (this being particularly the case in the German and Italian cases). With respect to the relative contribution of the various predictors included in the attitude battery, we rely on the Wald statistic $^{7}$ (with higher values indicating a stronger impact of the predictor on the dependent variable). Two countries conform fully to our expectations: Italy and the Netherlands. In both cases, in fact, we witness a substantial increase in the predictive power of leader evaluations. These are only modestly associated with the DV in the beginning of the time series, and it is

\footnotetext{
${ }^{7}$ The Wald statistic in logistic regression is comparable to the t-test in linear regression, and tells us whether the $b$ coefficient for the specific predictor is significantly different from zero (Field, 2009). In other words, is a measure of association between the independent and the dependent variable. Although this statistic tends to inflate the standard error when the regression coefficient is large, its use in the case at hand is justified by the substantially similar magnitude of the regression estimates.
} 
voters' placement on the left-right scale to play the foremost part. Yet in the period between 2002 (The Netherlands) and 2006 (Italy) the pattern is fully reversed, with both leaders' evaluations featuring the highest value of the Wald statistic in the respective model. As to Britain and Germany, there is no linear pattern (in the former leader evaluations are by and large the key predictors; in the latter they always are) but conclusions are the same. In spite of the different leaders being evaluated, their different personalities, and the different political and institutional contexts in which these evaluations are taking place, our findings seem to point to the conclusion that nowadays individual feelings of attachment to parties in these four democracies are best explained by individuals’ attitudes towards party leaders.

Additional evidence aimed at disentangling the causal direction of the link between leader evaluations and partisanship is presented in Table 4. We make use of Granger's concept of causality, as already employed for similar purposes by Midtbø (1997) and Jenssen and Aalberg (2006). Based on the assumption that cause precedes effect (Granger, 1969), Granger's causality test allows us to assess the actual point of departure in the relationship between party leader evaluation and partisanship. If the former is to be interpreted as causally prior to the latter, this should reflect in a stronger statistical association between leader evaluation at $\mathrm{t}_{1}$ and partisanship at $\mathrm{t}_{2}[L->P]$, as compared to that between partisanship at $\mathrm{t}_{1}$ and leader evaluation at $t_{2}[P->L]$. This expectation is tested, for illustrative purposes, on the British (2005) and Italian (2006) cases $^{8}$. As it turns out, the effect of leader evaluations at $t_{1}$ on partisanship at $t_{2}$ (controlled for partisanship at $t_{1}$ ) is in every instance stronger than the effect of partisanship at $t_{1}$ on leader evaluation at $t_{2}$ (controlled for leader evaluation at $t_{1}$ ). Furthermore, the relative magnitude of these effects speaks unmistakably in favor of the

\footnotetext{
8 These are in fact the only two surveys (among those employed in the analysis) in which partisanship and leader evaluation questions have been asked to the same respondents in both pre-election and a post-election waves. In this analysis, the strength of partisan attachment is also taken into account. Partisanship is thus scored as follows: (0) respondent is not identified with the party; (1) respondent leans towards the party; (2) respondent is weakly attached to the party; (3) respondent is strongly attached to the party.
} 
hypothesized direction of the relationship. The $[L->P]$ coefficient overcomes in fact the $[P$ -

$>$ L] coefficient by a 2-to-1 factor in the case of Italian Left-Democrats and British Conservatives, by a 3-to-1 factor in the case of British Labour, and by a 6-to-1 factor in the case of Forza Italia.

<--- Table 4 about here --->

\section{Discussion and Concluding Remarks}

In this paper, we hope to have shown the substantial changes occurred in the last two decades in the origins and content of mass partisanship in Britain, Germany, Italy, and the Netherlands. Although the relatively few and recent points in time covered in our analysis did not allow to fully assess the long-term decline of pre-existing social identities as determinants of individual feelings of attachment to parties, we can nonetheless affirm that contemporary partisanship appears increasingly shaped by voters’ attitudes towards more visible partisan objects, such as issue stands and individual leaders. As argued at the beginning of this paper, we are inclined to impute such change to the process of transformation undergone by former class-mass parties in Western Europe as a response to the progressive erosion of traditional group affiliations. The decline of class and religious cleavages, along with the fall of ideologies, has forced these parties to reshape their appeal in order to extend the electoral basin beyond the socio-ideological cleavages to which they usually referred. Based on the idea that partisanship is responsive to the set of alternatives available in a political system, our analysis has indeed demonstrated that such transformations at the party level are clearly reflected in the dynamics of partisan alignment at the individual level - nowadays a matter of attitudes rather than identity. 
With respect to attitudes themselves, we have shown the primacy of leader evaluations as opposed to issue proximity and performance assessments. This finding links well with the notion of candidate-centered politics (Wattenberg, 1991), whereby voters' attention is thought to shift from political parties and issues to individual politicians and their personal characteristics. The evidence presented here supports this notion, and elaborates on one of its crucial implications: namely, that different ways of thinking about politics can lead to different ways of relating to politics. A note of caution is in order. The main hypothesis of this study implies a causal relationship between leader evaluations and the development of partisan ties - a causal relationship which could only be tested on a handful of cases due to data availability. Broader panel studies will certainly supply more systematic evidence for the direction of this causal process (Holmberg, 2007). If any, the merit of this paper is that of having provided a different perspective on the relationship between parties, leaders, and voters’ political attitudes for future research in the field.

What are the main implications of our findings? The first, and probably most notable implication relates to the relative place of partisanship and leader evaluations in the voting calculus of individual voters. Against the common wisdom that sees popular party leaders as a fundamental asset for their parties, the scientific community has been almost unanimous in downplaying the electoral effects of leader images in democratic elections, in virtue of the pre-eminent role played by pre-existing partisan affiliations on voters’ choice (King, 2002). The empirical evidence presented in this paper represents, in our opinion, a chance to resolve this tension. In the light of the increasingly tighter relationship between party leader evaluations and individual feelings of closeness to their parties, we believe that the electoral effect of an attractive leader needs not to be found in the net gain of votes due to his/her strictly personal appeal, but rather in the improved image in voters' mind of the party he leads 
and 'personifies' (Curtice, 2003; McAllister, 2007; Barisione, 2009). In this sense, attitudes toward party leaders can be thought to affect voting choices through partisanship.

Overall, our findings point to the crucial role that political psychology can play in our understanding of democratic elections' outcomes. In times of social and electoral dealignment, a psychological approach to the study of political attitudes and behavior at the micro-level can lead to new insights and supplement in many ways traditional explanations based on macro-sociological factors. Eventually, political psychology can also enhance our understanding of the mental processes underlying voters' choice - the often neglected how question of electoral research (Houghton, 2009). If partisanship is to be conceived (as we argued in this paper) as an individual attitude, then the application of attitude-behavior models (Fishbein and Ajzen, 1975) to the study of its electoral consequences seems a fruitful way to go. Also, a more systematic assessment of the determinants of individual attitudes towards political leaders in parliamentary setting seems in order. Building on the vast amount of literature dealing with the American case, future research could investigate in more detail the extent to which the appraisal of prime ministerial candidates is best explained as memorybased or rather as an online process (Lodge et al., 1995). The role of cognitive and affective forces should also be addressed more systematically. The latter, in particular, have been shown to play a key role in voters' appraisals of presidential candidates (Caprara and Zimbardo, 2004). Finally, in an era in which political communication is dominated by ever more sophisticated marketing techniques, the effect of leaders' facial appearances (Todorov et al., 2005) and non-verbal behavior (Masters and Sullivan, 1993) on voters should not be overlooked.

There are reasons to believe that these (and related) topics will be at the core of electoral politics' research agenda in the years to come. As hopefully shown by this article, a psychological perspective will most certainly add to our ability of answering such questions 
in political contexts increasingly connoted by partisan dealignment and the personalization of political power. 


\section{References List}

Andeweg, R. (2000). Fractiocracy? Limits to the Ascendancy of the Parliamentary Party Group in Dutch Politics. In R. Koole \& K. Heidar (eds.), Parliamentary Party Groups in European Democracies. London and New York: Routledge.

Andeweg, R.; Irwin, G. (2003). Governance and Politics in the Netherlands. London: Macmillian.

Arzheimer, K. (2006). Dead men walking? Party identification in Germany, 1977-2002. Electoral Studies, 25, 791-807.

Barisione, M. (2009). So what difference do leaders make? Candidates' images and the conditionality of leader effects on voting. Journal of Elections, Public Opinion and Parties, 19, 473-500.

Bartle, J.; Bellucci, P. (2009). Political parties and partisanship. Social identity and individual attitudes. London and New York: Routledge.

Bean, C.; Mughan, A. (1989). Leadership effects in parliamentary elections in Australia and Britain. American Political Science Review, 83, 1165-79.

Bellucci, P. (2006). Tracing the cognitive and affective roots of 'party competence': Italy and Britain, 2001. Electoral Studies, 25, 534-68.

Bellucci, P. (2007). Changing Models of Electoral Choice in Italy. Modern Italy, 12, 55-72.

Berglund, F.; Holmberg, S.; Schmitt, H.; Thomassen, J. (2005). Party Identification and Party Choice. In J. Thomassen (ed.), The European Voter. Oxford: Oxford University Press.

Brettschneider, F.; Gabriel, O. (2002). The Nonpersonalization of Voting Behaviour in Germany. In A. King (ed.), Leaders' Personality and the Outcomes of Democratic Elections. Oxford: Oxford University Press. 
Budge, I.; Crewe, I.; Farlie, D. (1976). Party Identification and Beyond. Hoboken, NJ: John Wiley and Sons.

Butler, D.; Stokes, D. (1969). Political Change in Britain. London: Macmillan.

Campbell, A.; Converse, P.; Miller, W.; Stokes, D. (1960). The American Voter. Chicago and London: The University of Chicago Press.

Campus, D. (2010). Mediatization and Personalization of Politics in Italy and France: the cases of Berlusconi and Sarkozy. International Journal of Press/Politics 15: 219-35.

Caprara, G.; Zimbardo, P. (2004). Personalizing politics. American Psychologist, 59, 581-94.

Clarke, H.; Sanders, D.; Stewart, M.; Whiteley, P. (2004). Political choice in Britain. Oxford: Oxford University Press.

Converse, P. (1995). Foreword. In R. Petty \& J. Krosnick (eds.), Attitude Strength: Antecedents and Consequences. Mahwah, NJ: Lawrence Erlbaum Associates.

Couldry, N. (2009). Mediatization or mediation? Alternative understandings of the emergent space of digital storytelling. International Journal of Press/Politics 15: 60-76.

Crewe, I. (1976). Party Identification Theory and Political Change in Britain. In I. Budge, I. Crewe \& D. Farlie (eds.), Party Identification and Beyond. Hoboken, NJ: John Wiley and Sons.

Crewe, I.; Sarlvik, B.; Alt, J. (1977). Partisan Dealignment in Britain, 1964-74. British Journal of Political Science, 7, 129-90.

Curtice, J. (2003). Elections as beauty contests: Do the rules matter? Paper presented at the International Conference on 'Portugal at the Polls', Lisbon, 27-28 February. 
Daalder, H. (2002). Parties: Denied, Dismissed, or Redundant? A Critique. In R. Gunther, J. Montero \& J. Linz (eds.), Political Parties: Old Concepts and New Challenges. Oxford: Oxford University Press.

Dalton, R. (1996). Comparative Politics: Micro-Behavioural Perspectives. In R. Goodin \& H. Klingemann (eds.), A New Handbook of Political Science. New York: Oxford University Press.

Dalton, R. (2000). The Decline of Party Identifications. In R. Dalton \& M. Wattenberg (eds.), Parties Without Partisans: Political Change in Advanced Industrial Democracies. Oxford: Oxford University Press.

Dalton, R. (2010). Ideology, Parisanship and Democratic Development. In L. LeDuc, R. Niemi \& P. Norris (eds.), Comparing Democracies 3. Elections and Voting in the $21^{\text {st }}$ Century. London: Sage.

Dalton, R.; McAllister, I.; Wattenberg, M. (2000). The consequences of partisan dealignment. In R. Dalton \& M. Wattenberg (eds.), Parties Without Partisans: Political Change in Advanced Industrial Democracies. Oxford: Oxford University Press.

Dalton, R.; Wattenberg, M. (2000). Parties Without Partisans: Political Change in Advanced Industrial Democracies. Oxford: Oxford University Press.

Denver, D. (2007) Elections and voters in Britain. Basingstoke: Palgrave Macmillan.

Downs, A. (1957). An Economic Theory of Democracy. New York: Harper.

Eagly, A.; Chaiken, S. (1993). The Psychology of Attitudes. Orlando, FL: Harcourt Brace Jovanovich.

Evans, G.; Andersen, R. (2005). The impact of party leaders: how Blair lost Labour votes. Parliamentary Affairs, 58, 818-836. 
Farrell, D. (1996). Campaign strategies and tactics. In L. LeDuc, R. Niemi \& P. Norris (eds.), Comparing democracies. Elections and voting in global perspective. Thousand Oaks, CA: Sage.

Farrell, D.; Webb, P. (2000). Political Parties as Campaign Organizations. In R. Dalton \& M. Wattenberg (eds.), Parties Without Partisans: Political Change in Advanced Industrial Democracies. Oxford: Oxford University Press.

Field, A. (2009). Discovering statistics using SPSS. Los Angeles and London : Sage.

Fiers, S.; Krouwel, A. (2005). The Low Countries: From 'Prime Minister' to PresidentMinister. In T. Poguntke \& P. Webb (eds.), The Presidentialization of Politics. A Comparative Study of Modern Democracies. Oxford: Oxford University Press.

Fiorina, M. (1981). Retrospective Voting in American National Elections. New Haven: Yale University Press.

Fiorina, M. (2002). Parties and partisanship: a 40-year retrospective. Political Behaviour, 24, 93-115.

Fishbein, M; Ajzen, I. (1975). Belief, Attitude, Intention, and Behavior: An Introduction in Theory and Research. Reading, MA: Addison-Wesley.

Franklin, M.; Mackie, T.; Valen, H. (1992). Electoral change: Responses to evolving social and attitudinal structures in Western countries. Cambridge: Cambridge University Press.

Granger, C. (1969). Investigating causal relations by econometric models and cross-spectral methods. Econometrica, 37, 424-438.

Greene, S. (2001). The Role of Character Assessments in Presidential Approval. American Politics Research, 29, 196-210. 
Gunther, R.; Diamond, L. (2003). Species of Political Parties. A New Typology. Party Politics, 9, 167-199.

't Hart, P. (2009). Political Psychology: Exploring the human factor in political life. In D. Marsh \& G. Stoker (eds.), Theory and Methods in Political Science. Basingstoke: Palgrave.

Holmberg, S. (1994). Party Identification Compared across the Atlantic. In K. Jennings \& T. Mann (eds.), Elections at Home and Abroad. Ann Arbor: The University of Michigan Press.

Holmberg, S. (2007). Partisanship reconsidered. In R. Dalton \& H. Klingemann (eds.), The Oxford Handbook of Political Behaviour. Oxford: Oxford University Press.

Houghton, D. (2009). Political psychology : situations, individuals, and cases. New York and London: Routledge.

Howell, D. (2009). Statistical methods for psychology. Starnford: Cengage Learning.

Inglehart, R.; Klingemann, H. (1976). Party Identification, Ideological Preference and the Left-Right Dimensions among Western Mass Publics. In I. Budge, I. Crewe \& D. Farlie (eds.), Party Identification and Beyond. Hoboken, NJ: John Wiley and Sons.

Irwin, G.; van Holsteyn, J. (1989). Towards a more open model of competition. West European Politics, 12, 112-138.

Jenssen, A.; Aalberg, T. (2006). Party-leader effects in Norway: A multi-methods approach. Electoral Studies, 25, 248-269.

Kinder, D. (1986). Presidential character revisited. In R. Lau \& D. Sears (eds.), Political cognition. Hillsdale, NJ: Lawrence Erlbaum. 
King, A. (2002). Leaders' Personalities and the Outcomes of Democratic Elections. Oxford: Oxford University Press.

Kirchheimer, O. (1966). The transformation of the Western European party system. In J. LaPalombara \& M. Weiner (eds.), Political parties and political development. Princeton: Princeton University Press.

Kleinnijenhuis, J.; Oegema, D.; de Ridder, J.; van Hoof, A.; Vliegenthart, R. (2003). De puinhopen in het niews. De role van de media bij de Tweede-Kamerverkiezingen van 2002. Alphen aan den Rijn: Kluwer.

Lipset, S.; Rokkan, S. (1967). Party systems and voter alignments. New York: The Free Press.

Lodge, M.; Stroh, P.; Wahlke, J. (1995). Black-box models of candidate evaluation. Political Behavior, 12, 5-18.

Mair, P.; Muller, W.; Plasser, F. (2004). Political parties and electoral change: party responses to electoral markets. London: Sage.

Masters, R.; Sullivan, D. (1993). Nonverbal behavior and leadership: Emotion and cognition in political information processing. In S. Iyengar \& W. McGuire (eds.), Explorations in political psychology. Durham, NC: Duke University Press.

McAllister, I. (1996). Leaders. In L. LeDuc, R. Niemi \& P. Norris (eds.), Comparing democracies. Elections and voting in global perspective. Thousand Oaks, CA: Sage.

McAllister, I. (2007). The Personalization of Politics. In R. Dalton \& H. Klingemann (eds.), The Oxford Handbook of Political Behaviour. Oxford: Oxford University Press.

Midtbø, T. (1997). The electoral effect of party leader approval in Norway. Scandinavian Political Studies, 20, 135-158. 
Miller, A.; Wattenberg, M.; Malanchuk, O. (1986). Schematic assessments of presidential candidates. American Political Science Review, 80, 521-40.

Miller, W. (1991). Party identification, realignment, and party voting: back to the basics. American Political Science Review, 85, 557-68.

Mughan, A. (2000). Media and the Presidentialization of Parliamentary Elections. London: Palgrave.

Oskarson, M. (2005). Social Structure and Party Choice. In J. Thomassen (ed.), The European Voter. Oxford: Oxford University Press.

Page, B.; Jones, C. (1979). Reciprocal effects of policy preferences, party loyalties and the vote. American Political Science Review, 73, 1071-90.

Parisi, A.; Pasquino, G. (1977). Relazioni partiti-elettori e tipi di voto. In A. Parisi \& G. Pasquino (eds.), Continuità e mutamento elettorale in Italia. Bologna: Il Mulino.

Pierce, P. (1993). Political sophistication and the use of candidate traits in candidate evaluation. Political Psychology, 14, 21-36.

Poguntke, T. (2005). A Presidentializing Party State? The Federal Republic of Germany. In T. Poguntke \& P. Webb (eds.), The Presidentialization of Politics. A Comparative Study of Modern Democracies. Oxford: Oxford University Press.

Popkin, S. (1991). The Reasoning Voter. Chicago: University of Chicago Press.

Rahn, W.; Aldrich, J.; Borgida, E.; Sullivan, D. (1990). A social-cognitive model of candidate appraisal. In J. Ferejohn \& J. Kuklinski (eds.), Information and Democratic Processes. Urbana and Chicago: University of Illinois Press.

Richardson, B. (1991). European party loyalties revisited. American Political Science Review, 85, 751-75. 
Rosema, M. (2006). Partisanship, candidate evaluations, and prospective voting. Electoral Studies, 25, 467-88.

Saalfeld, T. (2000). Germany: Stable Parties, Chancellor Democracy, and the Art of Informal Settlement. In W. Müller \& K. Strøm (eds.), Coalition Governments in Western Europe. Oxford: Oxford University Press.

Schmitt, H. (2009). Partisanship in Nine Western Democracies: Causes and Consequences. In J. Bartle and P. Bellucci (eds.), Political parties and partisanship. Social identity and individual attitudes. London and New York: Routledge.

Stokes, D. (1963). Spatial models of party competition. American Political Science Review, 57, 368-77.

Sullivan, J., Aldrich, J., Borgida, E., Rahn, W. (1990). Candidate appraisal and human nature: Man and Superman in the 1984 election. Political Psychology, 11, 459-84.

Thomassen, J. (1976). Party Identification as a Cross-National Concept: Its Meaning in The Netherlands. In I. Budge, I. Crewe \& D. Farlie (eds.), Party Identification and Beyond. Hoboken, NJ: John Wiley and Sons.

Thomassen, J.; Rosema, M. (2009). Party Identification Revisited. In J. Bartle \& P. Bellucci (eds.), Political parties and partisanship. Social identity and individual attitudes. London and New York: Routledge.

Todorov, A.; Mandisodza, A.; Goren, A.; Hall, C. (2005). Inferences of Competence from Faces Predict Election Outcomes. Science, 308, 1623-26.

Wattenberg, M. (1991). The Rise of Candidate-Centered Politics. Cambridge, Mass: Oxford University Press. 
Webb, P. (2004). The reaction of British parties to the erosion of voter loyalties. In P. Mair, W. Muller \& F. Plasser (eds.), Political parties and electoral change: party responses to electoral markets. London: Sage.

Weisberg, H.; Greene, S. (2003). The political psychology of party identification. In M. MacKuen \& G. Rabinowitz (eds.), Electoral Democracy. Ann Arbor: University of Michigan Press. 
Figure 1 - Percentage of Voters Close to a Party (1979-2008)

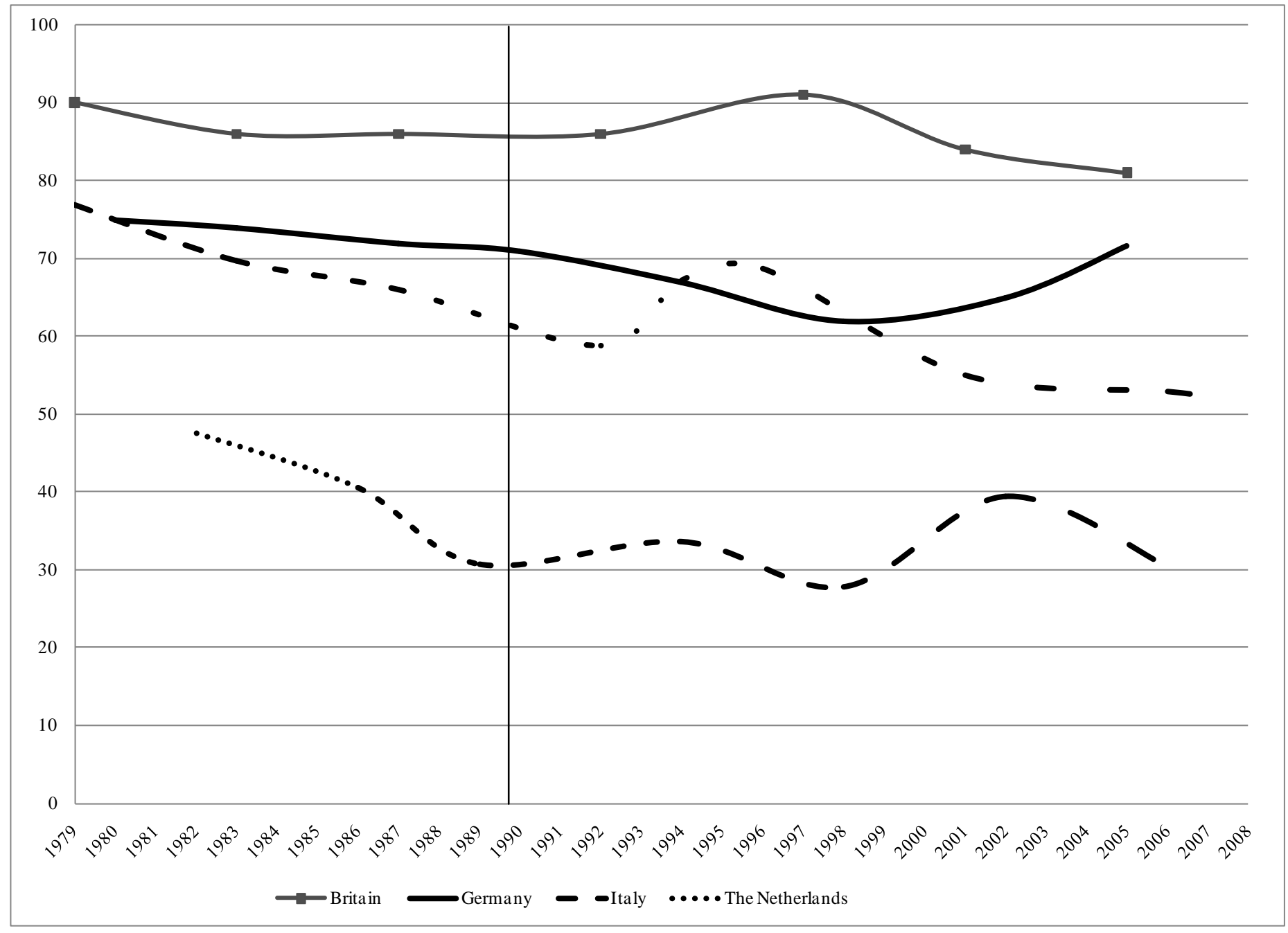

Sources: [DE] Mair et al., 2004; German Federal Election Study 2005 [IT] Eurobarometer 1979-1994; Itanes 1996-2008 [NL] Thomassen and Rosema, 2009 [UK] Mair et al., 2004; Denver, 2007 
Table 1 - Point-biserial correlations: leader evaluation and partisanship (1990-2006)

\begin{tabular}{|c|c|c|c|c|c|c|c|c|c|c|c|}
\hline \multicolumn{3}{|c|}{ Germany (1994-2005) } & \multicolumn{3}{|c|}{ Italy (1990-2006) } & \multicolumn{3}{|c|}{ The Netherlands (1994-1998) } & \multicolumn{3}{|c|}{ United Kingdom (1992-2005) } \\
\hline Year & SPD & CDU & Year & PCI/PDS & DC/FI & Year & $\operatorname{PvdA}$ & CDA & Year & Lab. & Con. \\
\hline 1994 & .414 & .559 & 1990 & .350 & .350 & 1994 & .236 & .248 & 1992 & .449 & .566 \\
\hline 1998 & .422 & .409 & 1996 & .454 & .389 & 1998 & .204 & .359 & 1997 & .510 & .541 \\
\hline $\begin{array}{l}\text { Mean } \\
\text { 1990s }\end{array}$ & .418 & .483 & $\begin{array}{l}\text { Mean } \\
\text { 1990s }\end{array}$ & .402 & .370 & $\begin{array}{l}\text { Mean } \\
\text { 1990s }\end{array}$ & .220 & .304 & $\begin{array}{l}\text { Mean } \\
\text { 1990s }\end{array}$ & .480 & .554 \\
\hline 2002 & .468 & .540 & 2001 & .391 & .415 & 2002 & .265 & .302 & 2001 & .601 & .482 \\
\hline 2005 & .516 & .457 & 2006 & .435 & .496 & 2006 & .370 & .352 & 2005 & .460 & .455 \\
\hline $\begin{array}{l}\text { Mean } \\
\text { 2000s }\end{array}$ & .492 & .499 & $\begin{array}{l}\text { Mean } \\
\text { 2000s }\end{array}$ & .413 & .456 & $\begin{array}{l}\text { Mean } \\
2000 s\end{array}$ & .318 & .326 & $\begin{array}{l}\text { Mean } \\
\text { 2000s }\end{array}$ & .531 & .469 \\
\hline
\end{tabular}


Figure 2 - Variance in partisanship explained by identity items

\begin{tabular}{|c|c|c|c|c|c|c|c|c|c|c|c|c|}
\hline & 1990 & 1992 & 1994 & 1996 & 1997 & 1998 & 2001 & 2002 & 2005 & 2006 & 2008 & $\boldsymbol{b}$ \\
\hline \multicolumn{13}{|l|}{ Britain } \\
\hline Labour & - & $\begin{array}{c}, 14 \\
(3838,373)\end{array}$ & - & - & $\begin{array}{c}, 09 \\
(4511,288)\end{array}$ & - & $\begin{array}{c}, 14 \\
(1342,660)\end{array}$ & - & $\begin{array}{c}, 08 \\
(1649,835)\end{array}$ & - & - & $-0,003$ \\
\hline Conservatives & - & $\begin{array}{c}, 13 \\
(4063,385)\end{array}$ & - & - & $\begin{array}{c}, 15 \\
(3688,892)\end{array}$ & - & $\begin{array}{c}, 17 \\
(1012,770)\end{array}$ & - & $\begin{array}{c}, 12 \\
(1314,075)\end{array}$ & - & - & 0,001 \\
\hline \multicolumn{13}{|l|}{ Germany } \\
\hline SPD & $\begin{array}{c}, 03 \\
(1564,809)\end{array}$ & - & $\begin{array}{c}, 06 \\
(1246,942)\end{array}$ & - & - & $\begin{array}{c}, 04 \\
(1393,503)\end{array}$ & - & $\begin{array}{c}, 04 \\
(3611,570)\end{array}$ & $\begin{array}{c}, 04 \\
(1865,083)\end{array}$ & - & - & $-0,001$ \\
\hline $\mathrm{CDU}$ & $\begin{array}{c}, 07 \\
(1629,720)\end{array}$ & - & $\begin{array}{c}, 11 \\
(1371,305)\end{array}$ & - & - & $\begin{array}{c}, 11 \\
(1286,526)\end{array}$ & - & $\begin{array}{c}, 14 \\
(3272,452)\end{array}$ & $\begin{array}{c}, 07 \\
(1773,499)\end{array}$ & - & - & 0,001 \\
\hline \multicolumn{13}{|l|}{ Italy } \\
\hline PCI-PDS-PD & $\begin{array}{c}, 14 \\
(972,320)\end{array}$ & - & - & $\begin{array}{c}, 10 \\
(2391,867)\end{array}$ & - & - & $\begin{array}{c}, 05 \\
(2056,589)\end{array}$ & - & - & $\begin{array}{c}, 05 \\
(1168,779)\end{array}$ & $\begin{array}{c}, 04 \\
(2041,318)\end{array}$ & $-0,005$ \\
\hline DC-FI-PdL & $\begin{array}{c}, 10 \\
(1186,240)\end{array}$ & - & - & $\begin{array}{c}, 03 \\
(1556,065)\end{array}$ & - & - & $\begin{array}{c}, 01 \\
(2459,147)\end{array}$ & - & - & $\begin{array}{c}, 00 \\
(1040,760)\end{array}$ & $\begin{array}{c}, 01 \\
(1962,857)\end{array}$ & $-0,006$ \\
\hline \multicolumn{13}{|l|}{ The Netherlands } \\
\hline PvdA & - & - & $\begin{array}{c}, 13 \\
(847,829)\end{array}$ & - & - & $\begin{array}{c}, 13 \\
(1059,395)\end{array}$ & - & $\begin{array}{c}, 11 \\
(914,278)\end{array}$ & - & $\begin{array}{c}, 04 \\
(2107,661)\end{array}$ & - & $-0,001$ \\
\hline CDA & - & - & $\begin{array}{c}\text {,32 } \\
(678,415)\end{array}$ & - & - & $\begin{array}{c}\text {,32 } \\
(824,143)\end{array}$ & - & $\begin{array}{c}, 20 \\
(930,506)\end{array}$ & - & $\begin{array}{c}, 17 \\
(2070,992)\end{array}$ & - & $-0,014$ \\
\hline
\end{tabular}

Note: Dependent variable: partisanship (dummy) - Predictors included: church attendance, union membership, social class, controls (age, gender, education) Cell entries are Nagelkerke R-squared coefficients (-2 Log likelihood in parenthesis) 
Table 3a - Multinomial Logistic Regression Estimates, Britain (1992-2005)

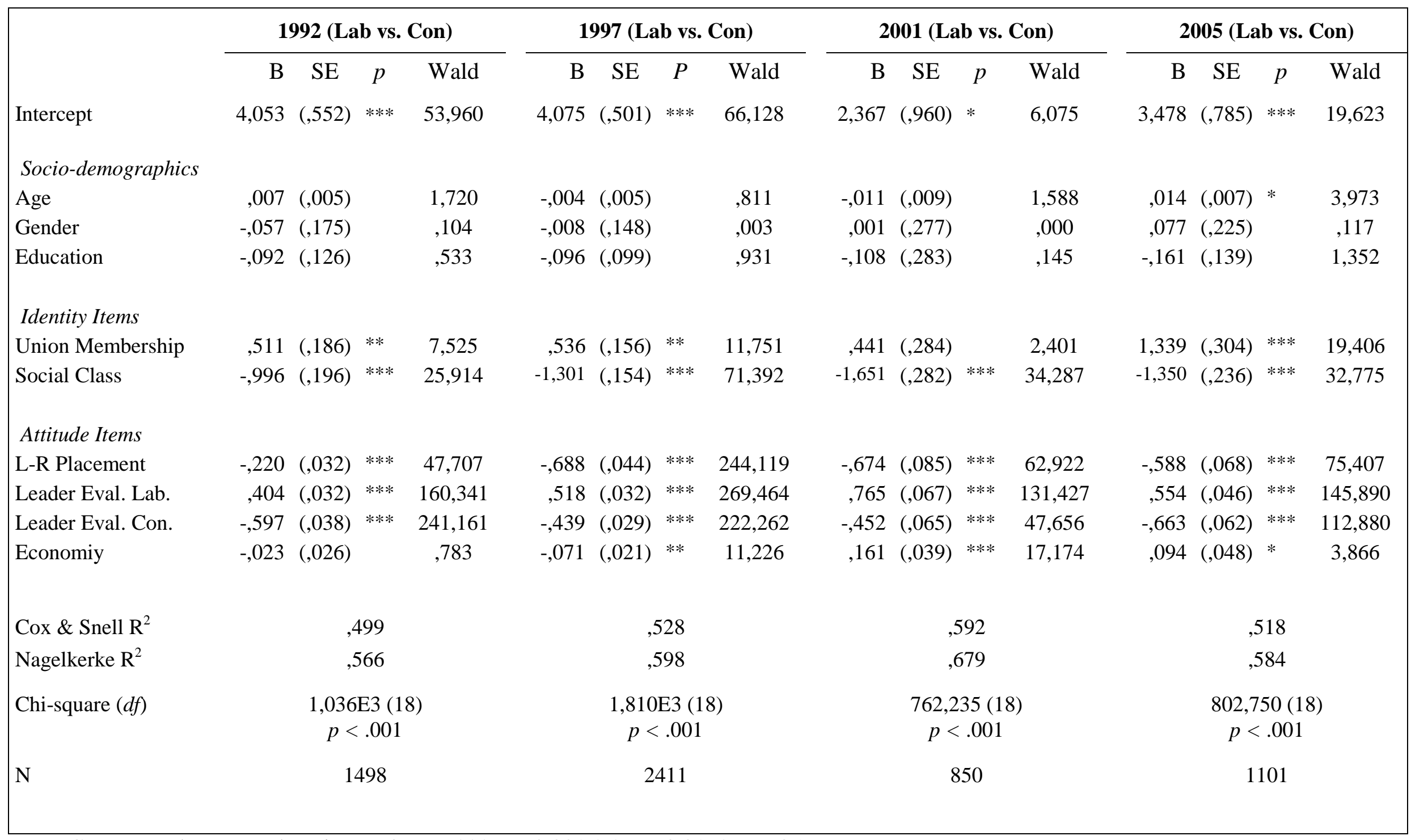

Note: Contrast Labour vs. others is not shown. ${ }^{* * *} \mathrm{p}<0.001,{ }^{*} * \mathrm{p}<0.01,{ }^{*} \mathrm{p}<.05$ 
Table 3b - Multinomial Logistic Regression Estimates, Germany (1990-2005)

\begin{tabular}{|c|c|c|c|c|c|c|c|c|c|c|c|c|c|c|c|c|c|c|c|c|}
\hline & \multicolumn{4}{|c|}{1990 (SPD vs. CDU) } & \multicolumn{4}{|c|}{1994 (SPD vs. CDU) } & \multicolumn{4}{|c|}{1998 (SPD vs. CDU) } & \multicolumn{4}{|c|}{2002 (SPD vs. CSU) } & \multicolumn{4}{|c|}{2005 (SPD vs. CDU) } \\
\hline & B & SE & $p$ & Wald & B & SE & $p$ & Wald & B & SE & $p$ & Wald & $\mathrm{B}$ & SE & $p$ & Wald & B & SE & $p$ & Wald \\
\hline Intercept & 7,323 & $(1,357)$ & $* * *$ & 29,124 & 4,551 & $(1,031)$ & $* * *$ & 19,469 & 2,686 & $(, 938)$ & $* *$ & 8,191 & 1,497 & $(, 649)$ & * & 5,320 & 2,070 & $(, 886)$ & * & 5,461 \\
\hline \multicolumn{21}{|l|}{ Socio-demographics } \\
\hline Age &, 044 & $(, 009)$ & $* * *$ & 23,202 &,- 010 & $(, 008)$ & & 1,830 &,- 004 & $(, 007)$ & & 301 & ,002 & $(, 004)$ & & ,295 & ,000 & $(, 006)$ & & ,005 \\
\hline Gender & ,076 & $(, 280)$ & & ,074 & ,533 & $(, 240)$ & $*$ & 4,934 & ,120 & $(, 224)$ & & ,287 & ,079 & $(, 135)$ & & ,342 &,- 056 & $(, 196)$ & & ,083 \\
\hline Education &,- 203 & $(, 182)$ & & 1,246 &,- 224 & $(, 170)$ & & 1,721 &,- 140 & $(, 145)$ & & 932 &,- 246 & $(, 150)$ & & 2,712 &,- 007 & $(, 137)$ & & ,003 \\
\hline \multicolumn{21}{|l|}{ Identity Items } \\
\hline Union Membership & ,855 & $(, 377)$ & $*$ & 5,152 & ,701 & $(, 317)$ & * & 4,900 & ,511 & $(, 301)$ & & 2,886 &, 573 & $(, 217)$ & $* *$ & 6,970 &,- 223 & $(, 312)$ & &, 510 \\
\hline Church Attendance &,- 553 & $(, 106)$ & $* * *$ & 27,445 &,- 106 & $(, 101)$ & & 1,115 &,- 387 & $(, 093)$ & $* * *$ & 17,234 &,- 215 & $(, 056)$ & $* * *$ & 14,942 &,- 184 & $(, 077)$ & * & 5,772 \\
\hline \multicolumn{21}{|l|}{ Attitude Items } \\
\hline L-R Placement &,- 512 & $(, 072)$ & $* * *$ & 49,999 &,- 485 & $(, 079)$ & $* * *$ & 37,888 &,- 294 & $(, 057)$ & $* * *$ & 26,525 &,- 380 & $(, 042)$ & $* * *$ & 81,029 &,- 505 & $(, 061)$ & $* * *$ & 68,563 \\
\hline Leader Eval. SPD &, 560 & $(, 057)$ & $* * *$ & 95,435 & ,644 & $(, 058)$ & $* * *$ & 122,894 & ,598 & $(, 048)$ & $* * *$ & 153,959 &, 587 & $(, 035)$ & $* * *$ & 274,302 & ,753 & $(, 052)$ & $* * *$ & 209,327 \\
\hline Leader Eval. CDU &,- 967 & $(, 098)$ & $* * *$ & 97,680 &,- 784 & $(, 060)$ & $* * *$ & 172,024 &,- 456 & $(, 044)$ & $* * *$ & 109,725 &,- 508 & $(, 032)$ & $* * *$ & 251,905 &,- 518 & $(, 046)$ & $* * *$ & 125,968 \\
\hline Economiy &,- 022 & $(, 059)$ & & ,136 &,- 068 & $(, 076)$ & & ,798 &,- 176 & $(, 056)$ & $* *$ & 9,973 & ,086 & $(, 035)$ & * & 6,107 & & not ave & ailable & \\
\hline Cox \& Snell R² & \multicolumn{4}{|c|}{,549 } & \multicolumn{4}{|c|}{,541 } & \multicolumn{4}{|c|}{ 419 } & \multicolumn{4}{|c|}{ 495 } & \multicolumn{4}{|c|}{, 541} \\
\hline Nagelkerke $\mathrm{R}^{2}$ & \multicolumn{4}{|c|}{ 619 } & \multicolumn{4}{|c|}{,611 } & \multicolumn{4}{|c|}{,478 } & \multicolumn{4}{|c|}{, 560} & \multicolumn{4}{|c|}{ 609 } \\
\hline Chi-square ( $d f)$ & \multicolumn{4}{|c|}{$\begin{array}{c}622,415(18) \\
\quad p<.001\end{array}$} & \multicolumn{4}{|c|}{$\begin{array}{c}840,770(18) \\
p<.001\end{array}$} & \multicolumn{4}{|c|}{$\begin{array}{c}609,640(18) \\
\quad p<.001\end{array}$} & \multicolumn{4}{|c|}{$\begin{array}{c}1,974 \mathrm{E} 3(18) \\
p<.001\end{array}$} & \multicolumn{4}{|c|}{$\begin{array}{c}1,093 \mathrm{E} 3(16) \\
p<.001\end{array}$} \\
\hline $\mathrm{N}$ & \multicolumn{4}{|c|}{782} & \multicolumn{4}{|c|}{1079} & \multicolumn{4}{|c|}{1121} & \multicolumn{4}{|c|}{2743} & \multicolumn{4}{|c|}{1404} \\
\hline
\end{tabular}


Table 3c - Multinomial Logistic Regression Estimates, Italy (1990-2008)

\begin{tabular}{|c|c|c|c|c|c|c|c|c|c|c|c|c|c|c|c|c|c|c|c|c|}
\hline & \multicolumn{4}{|c|}{1990 (PCI vs. DC) } & \multicolumn{4}{|c|}{1996 (PDS vs. FI) } & \multicolumn{4}{|c|}{2001 (DS vs. FI) } & \multicolumn{4}{|c|}{2006 (DS vs. FI) } & \multicolumn{4}{|c|}{2008 (PD vs. PDL) } \\
\hline & B & SE & $p$ & Wald & B & SE & $P$ & Wald & $\mathrm{B}$ & SE & $p$ & Wald & B & SE & $p$ & Wald & B & SE & $p$ & Wald \\
\hline Intercept & 4,601 & $(1,178)$ & $* * *$ & 15,253 & 5,609 & $(, 957)$ & $* * *$ & 34,325 & 4,192 & $(, 956)$ & $* * *$ & 19,225 & 3,962 & $(1,362)$ & $* *$ & 8,466 & 3,658 & $(1,151)$ & $* *$ & 10,095 \\
\hline \multicolumn{21}{|l|}{ Socio-demographics } \\
\hline Age &,- 019 & $(, 010)$ & & 3,398 & 001 & $(, 008)$ & & 027 &,- 004 & $(, 007)$ & & ,424 & ,008 & $(, 010)$ & & ,585 & ,007 & $(, 006)$ & & 1,259 \\
\hline Gender & ,156 & $(, 327)$ & & ,229 &,- 538 & $(, 225)$ & * & 5,709 &,- 147 & $(, 212)$ & & ,481 &,- 187 & $(, 281)$ & & ,443 &,- 445 & $(, 222)$ & * & 4,037 \\
\hline Education &,- 112 & $(, 220)$ & & ,259 &,- 057 & $(, 149)$ & & ,146 &,- 042 & $(, 142)$ & & ,089 &,- 118 & $(, 193)$ & & ,373 &,- 018 & $(, 145)$ & & 015 \\
\hline \multicolumn{21}{|l|}{ Identity Items } \\
\hline Union Membership &,- 356 & $(, 133)$ & $* *$ & 7,123 &,- 082 & $(, 084)$ & & 945 &,- 052 & $(, 081)$ & & 409 & ,055 & $(, 104)$ & & ,280 &,- 006 & $(, 073)$ & & ,006 \\
\hline Social Class &,- 514 & $(, 120)$ & $* * *$ & 18,402 &,- 154 & $(, 079)$ & & 3,742 &,- 130 & $(, 073)$ & & 3,132 &,- 067 & $(, 102)$ & & ,438 & ,029 & $(, 072)$ & & ,162 \\
\hline Church Attendance & ,354 & $(, 347)$ & & 1,040 & ,776 & $(, 280)$ & $* *$ & 7,687 & 991 & $(, 283)$ & $* * *$ & 12,286 &,- 139 & $(, 392)$ & & ,125 & ,497 & $(, 626)$ & & ,631 \\
\hline \multicolumn{21}{|l|}{ Attitude Items } \\
\hline L-R Placement &,- 680 & $(, 086)$ & $* * *$ & 62,596 &,- 509 & $(, 059)$ & $* * *$ & 73,259 &,- 571 & $(, 064)$ & $* * *$ & 79,259 &,- 294 & $(, 089)$ & $* *$ & 10,845 &,- 499 & $(, 061)$ & $* * *$ & 66,116 \\
\hline Leader Eval. (Left) & ,395 & $(, 071)$ & $* * *$ & 30,499 & ,636 & $(, 061)$ & $* * *$ & 107,736 & ,503 & $(, 059)$ & $* * *$ & 73,032 & ,606 & $(, 083)$ & $* * *$ & 52,724 & ,732 & $(, 065)$ & $* * *$ & 128,476 \\
\hline Leader Eval. (Right) &,- 391 & $(, 075)$ & $* * *$ & 27,139 &,- 815 & $(, 070)$ & $* * *$ & 135,102 &,- 783 & $(, 059)$ & $* * *$ & 173,767 &,- 798 & $(, 088)$ & $* * *$ & 82,196 &,- 855 & $(, 065)$ & $* * *$ & 173,001 \\
\hline Economiy & ,096 & $(, 043)$ & $*$ & 4,970 &,- 026 & $(, 039)$ & & ,424 & ,167 & $(, 057)$ & $* *$ & 8,716 &,- 124 & $(, 082)$ & & 2,302 &,- 026 & ,065 & & 157 \\
\hline Cox \& Snell R 2 & \multicolumn{4}{|c|}{ 394 } & \multicolumn{4}{|c|}{ 458 } & \multicolumn{4}{|c|}{,425 } & \multicolumn{4}{|c|}{,433 } & \multicolumn{4}{|c|}{,460 } \\
\hline Nagelkerke $\mathrm{R}^{2}$ & \multicolumn{4}{|c|}{,463 } & \multicolumn{4}{|c|}{,558 } & \multicolumn{4}{|c|}{, 521} & \multicolumn{4}{|c|}{,524 } & \multicolumn{4}{|c|}{, 546} \\
\hline Chi-square ( $d f)$ & \multicolumn{4}{|c|}{$\begin{array}{c}349,576(20) \\
p<.001\end{array}$} & \multicolumn{4}{|c|}{$\begin{array}{c}1,215 \mathrm{E} 3(20) \\
p<.001\end{array}$} & \multicolumn{4}{|c|}{$\begin{array}{c}1,173 \mathrm{E} 3(20) \\
p<.001\end{array}$} & \multicolumn{4}{|c|}{$\begin{array}{c}641,465(20) \\
p<.001\end{array}$} & \multicolumn{4}{|c|}{$\begin{array}{c}1,096 \mathrm{E} 3(20) \\
p<.001\end{array}$} \\
\hline $\mathrm{N}$ & \multicolumn{4}{|c|}{698} & \multicolumn{4}{|c|}{1984} & \multicolumn{4}{|c|}{2121} & \multicolumn{4}{|c|}{1132} & \multicolumn{4}{|c|}{1780} \\
\hline
\end{tabular}

Note: Contrast centre-left parties vs. others is not shown. ${ }^{* * *} \mathrm{p}<0.001,{ }^{*} \mathrm{p}<0.01,{ }^{*} \mathrm{p}<.05$ 
Table 3d - Multinomial Logistic Regression Estimates, The Netherlands (1994-2006)

\begin{tabular}{|c|c|c|c|c|c|c|c|c|c|c|c|c|c|c|c|c|}
\hline & \multicolumn{4}{|c|}{1994 (PvdA vs. CDA) } & \multicolumn{4}{|c|}{1998 (PvdA vs. CDA) } & \multicolumn{4}{|c|}{2002 (PvdA vs. CDA) } & \multicolumn{4}{|c|}{2006 (PvdA vs. CDA) } \\
\hline & B & SE & $p$ & Wald & $\mathrm{B}$ & $\mathrm{SE}$ & $p$ & Wald & $\mathrm{B}$ & SE & $p$ & Wald & $\mathrm{B}$ & $\mathrm{SE}$ & $p$ & Wald \\
\hline Intercept & 3,185 & $(1,661)$ & & 3,679 & ,243 & $(1,778)$ & & ,019 & 1,941 & $(1,620)$ & & 1,435 & 2,196 & $(1,186)$ & & 3,431 \\
\hline \multicolumn{17}{|l|}{ Socio-demographics } \\
\hline Age &,- 008 & $(, 010)$ & & 661 &,- 020 & $(, 011)$ & & 3,714 & ,014 & $(, 009)$ & & 2,046 & 001 & $(, 006)$ & & ,016 \\
\hline Gender & ,342 & $(, 324)$ & & 1,119 &,- 600 & $(, 314)$ & & 3,647 & 317 & $(, 286)$ & & 1,231 &,- 409 & $(, 194)$ & * & 4,460 \\
\hline Education & ,020 & $(, 152)$ & & ,018 &,- 066 & $(, 165)$ & & ,163 & ,092 & $(, 147)$ & & ,392 &,- 100 & $(, 092)$ & & 1,186 \\
\hline \multicolumn{17}{|l|}{ Identity Items } \\
\hline Union Membership & 821 & $(, 358)$ & * & 5,268 & 610 & $(, 338)$ & & 3,253 & 242 & $(, 298)$ & & 658 &,- 168 & $(, 237)$ & &, 507 \\
\hline Social Class &,- 070 & $(, 169)$ & & 172 &,- 554 & $(, 184)$ & $* *$ & 9,066 &,- 174 & $(, 165)$ & & 1,109 &,- 049 & $(, 106)$ & & ,211 \\
\hline Church Attendance &,- 691 & $(, 116)$ & $* * *$ & 35,807 &,- 867 & $(, 122)$ & $* * *$ & 50,298 &,- 635 & $(, 122)$ & $* * *$ & 26,910 &,- 365 & $(, 053)$ & $* * *$ & 47,930 \\
\hline \multicolumn{17}{|l|}{ Attitude Items } \\
\hline L-R Placement &,- 497 & $(, 074)$ & $* * *$ & 45,085 &,- 565 & $(, 086)$ & $* * *$ & 43,150 &,- 270 & $(, 080)$ & $* *$ & 11,425 &,- 362 & $(, 055)$ & $* * *$ & 43,760 \\
\hline Leader Eval. PvdA & ,440 & $(, 099)$ & $* * *$ & 19,644 & ,614 & $(, 104)$ & $* * *$ & 35,014 & ,641 & $(, 081)$ & $* * *$ & 62,429 & ,680 & $(, 069)$ & $* * *$ & 98,231 \\
\hline Leader Eval. CDA &,- 623 & $(, 105)$ & $* * *$ & 34,942 &,- 790 & $(, 095)$ & $* * *$ & 69,452 &,- 737 & $(, 088)$ & $* * *$ & 70,287 &,- 674 & $(, 072)$ & $* * *$ & 87,384 \\
\hline Economiy &,- 079 & $(, 039)$ & $*$ & 4,181 & ,109 & $(, 036)$ & $* *$ & 9,073 & ,064 & $(, 031)$ & * & 4,289 &,- 121 & $(, 023)$ & $* * *$ & 27,503 \\
\hline Cox \& Snell $\mathrm{R}^{2}$ & \multicolumn{4}{|c|}{,318 } & \multicolumn{4}{|c|}{,352 } & \multicolumn{4}{|c|}{,297 } & \multicolumn{4}{|c|}{,386 } \\
\hline Nagelkerke $\mathrm{R}^{2}$ & \multicolumn{4}{|c|}{,442 } & \multicolumn{4}{|c|}{,502 } & \multicolumn{4}{|c|}{,405 } & \multicolumn{4}{|c|}{,462 } \\
\hline Chi-square ( $d f$ ) & \multicolumn{4}{|c|}{$\begin{array}{c}484,494(20) \\
\quad p<.001\end{array}$} & \multicolumn{4}{|c|}{$\begin{array}{c}667,130(20) \\
\quad p<.001\end{array}$} & \multicolumn{4}{|c|}{$\begin{array}{c}499,429(20) \\
p<.001\end{array}$} & \multicolumn{4}{|c|}{$\begin{array}{c}945,542(20) \\
p<.001\end{array}$} \\
\hline $\mathrm{N}$ & \multicolumn{4}{|c|}{1265} & \multicolumn{4}{|c|}{1536} & \multicolumn{4}{|c|}{1418} & \multicolumn{4}{|c|}{1937} \\
\hline
\end{tabular}

Note: Contrast PvdA vs. others is not shown. ${ }^{* * *} \mathrm{p}<0.001,{ }^{*} \mathrm{p}<0.01,{ }^{*} \mathrm{p}<.05$ 
Table 4-Granger's test of causality

\begin{tabular}{|c|c|c|c|c|c|}
\hline Party/leader & DV $_{\text {post-election }}$ & IVs $s_{\text {pre-election }}$ & B & $\mathbf{R}^{2}$ & $\mathbf{N}$ \\
\hline Britain, 2005 & & & & & \\
\hline Labour & Partisanship $\mathrm{T}_{2}$ & $\begin{array}{l}\text { Partisanship } \mathrm{T}_{1} \\
\text { Leader Eval. } \mathrm{T}_{1}[\mathbf{L}->\mathbf{P}]\end{array}$ & $\begin{array}{l}, 238 * \\
, 239 *\end{array}$ & ,15 & 2336 \\
\hline Tony Blair & Leader Eval. $\mathrm{T}_{2}$ & $\begin{array}{l}\text { Partisanship } \mathrm{T}_{1}[\mathbf{P}->\mathbf{L}] \\
\text { Leader Eval. } \mathrm{T}_{1}\end{array}$ & $\begin{array}{l}, \mathbf{0 6 8 *} \\
, 762 *\end{array}$ & ,61 & 2321 \\
\hline Conservatives & Partisanship $\mathrm{T}_{2}$ & $\begin{array}{l}\text { Partisanship } \mathrm{T}_{1} \\
\text { Leader Eval. } \mathrm{T}_{1}[\mathbf{L}->\mathbf{P}]\end{array}$ & $\begin{array}{l}, 281^{*} \\
, 198 *\end{array}$ & ,15 & 2229 \\
\hline Michael Howard & Leader Eval. $\mathrm{T}_{2}$ & $\begin{array}{l}\text { Partisanship } \mathrm{T}_{1}[\mathbf{P}->\mathbf{L}] \\
\text { Leader Eval. } \mathrm{T}_{1}\end{array}$ & $\begin{array}{l}, \mathbf{1 1 1} * \\
, 611 *\end{array}$ & ,43 & 2195 \\
\hline Italy, 2006 & & & & & \\
\hline Democratici di Sinistra & Partisanship $\mathrm{T}_{2}$ & $\begin{array}{l}\text { Partisanship } \mathrm{T}_{1} \\
\text { Leader Eval. } \mathrm{T}_{1}[\mathbf{L}->\mathbf{P}]\end{array}$ & $\begin{array}{l}, 489 * \\
, \mathbf{1 9 8 *}\end{array}$ & ,36 & 1207 \\
\hline Piero Fassino & Leader Eval. $\mathrm{T}_{2}$ & $\begin{array}{l}\text { Partisanship } \mathrm{T}_{1}[\mathbf{P}->\mathbf{L}] \\
\text { Leader Eval. } \mathrm{T}_{1}\end{array}$ & $\begin{array}{l}, \mathbf{1 0 9} * \\
, 642 *\end{array}$ & ,49 & 1161 \\
\hline Forza Italia & Partisanship $\mathrm{T}_{2}$ & $\begin{array}{l}\text { Partisanship } \mathrm{T}_{1} \\
\text { Leader Eval. } \mathrm{T}_{1}[\mathbf{L} \text {-> P] }\end{array}$ & $\begin{array}{l}, 536 * \\
, \mathbf{1 6 1} *\end{array}$ & ,40 & 1318 \\
\hline Silvio Berlusconi & Leader Eval. $\mathrm{T}_{2}$ & $\begin{array}{l}\text { Partisanship } \mathrm{T}_{1}[\mathbf{P}->\mathbf{L}] \\
\text { Leader Eval. } \mathrm{T}_{1}\end{array}$ & $\begin{array}{l}, \mathbf{0 2 6} * \\
, 738^{*}\end{array}$ & ,56 & 1286 \\
\hline
\end{tabular}




\section{Appendix A - Data Sources}

\section{Britain}

1992-01 Hans-Dieter Klingemann, Hermann Schmitt, Bernhard Wessels and Tanja Binder. The European Voter Dataset. GESIS Cologne, Germany. ZA3911 Data file.

2005 Harold Clarke, David Sanders, Marianne Stewart and Paul Whitely. British Election Study 2005. National Centre for for Social Research. P2474 Data file.

\section{Germany}

1990-8 Hans-Dieter Klingemann, Hermann Schmitt, Bernhard Wessels and Tanja Binder. The European Voter Dataset. GESIS Cologne, Germany. ZA3911 Data file.

2002 Jurgen Falter, Oscar Gabriel and Hans Rattinger. Political Attitudes, Political Participation and Voter Conduct in United Germany 2002. GESIS Cologne, Germany. ZA3861 Data file.

2005 Steffen Kühnel, Oskar Niedermayer and Bettina Westle. Bürger und Parteien in einer veränderten Welt. Deutsche Gesellschaft für Wahlforschung. ZA 4332 Data file.

\section{Italy}

1990 Arturo Parisi and Hans Schadee. Italian National Election Study 1990. Istituto Cattaneo, Bologna.

1996 Piergiorgio Corbetta and Arturo Parisi. Italian National Election Study 1996. Istituto Cattaneo, Bologna.

2001 Mario Caciagli and Piergiorgio Corbetta. Italian National Election Study 2001. Istituto Cattaneo, Bologna.

2006 Paolo Bellucci and Paolo Segatti. Italian National Election Study. Istituto Cattaneo, Bologna.

2008 Paolo Bellucci and Paolo Segatti. Italian National Election Study 2008. Istituto Cattaneo, Bologna.

\section{The Netherlands}

1994 Stichting Kiezersonderzoek Nederland. Nationaal kiezersonderzoek 1994. Netherlands Institute for Scientific Information Services, Steinmetz Archive. P1208 Data file. 
1998 Kees Aarts, Henk van der Kolk and Marlies Kamp. Dutch Parliamentary Election Study 1998. Netherlands Institute for Scientific Information Services, Steinmetz Archive. P1415 Data file.

2002 Galen Irwin, Joop van Holsteyn and Jan den Ridder. Dutch Parliamentary Election Study 2002-2003. Netherlands Institute for Scientific Information Services, Steinmetz Archive. P1628 Data file.

2006 Kees Aarts, Henk van der Kolk, Martin Rosema and Hans Schmeets. Dutch Parliamentary Election Study 2006. Netherlands Institute for Scientific Information Services, Steinmetz Archive.

\section{Appendix B - Party Identification Question Wording}

\section{Britain}

"Generally speaking, do you think of yourself as Labour, Conservative, Liberal Democrat, or what?”

\section{Germany}

"Many people in the Federal Republic lead toward a particular party for a long time, although they may vote for a different party. How about you? Do you in general lean toward a particular party?”

\section{Italy}

"Is there any political party that you feel closer to than others?”

\section{The Netherlands}

"Many people think of themselves as adherents of a particular party, but there are many other people who do not regard themselves as such. How about you, do you regard yourself as an adherent of a political party or don't you?” 


\section{Appendix C - Variable codings}

\section{$\underline{\text { Socio-demographics }}$}

Gender: Male (0), Female (1)

Age: Age in years

\section{Educational Level}

[DE] Primary education (1), Secondary education (2), University education (3)

[IT] Elementary school (1), Middle school (2), High school (3), University (4)

[NL] Scale from lowest (1) to highest (5)

[UK] Primary education (1), University (2), College (3)

\section{$\underline{\text { Identity items }}$}

\section{Frequency of church attendance}

[DE] Never (1), Once a year (2), Several times a year (3), Once a month or more (4), Once a week or more (5)

[IT] [NL] Never (1), 2-3 times a year (2), Once a month (3), 2-3 times a month (4), Once a week or more (5)

\section{Union membership}

No (0), Yes (1)

\section{Social class}

[IT] Working class (1), Rural petite bourgeoisie (2), Urban petite bourgeoisie (3), White collar middle class (4), Bourgeoisie (5)

[NL] Working class (1), Upper working class (2), Middle class (3), Upper middle class (4), Upper class (5)

[UK] Working class (1), Middle class (2)

\section{$\underline{\text { Attitude items }}$}

\section{Left-right self placement}

Scale from 0 ('left') to 10 ('right')

\section{Leader evaluations}

Scale from 0 ('completely negative evaluation') to 10 ('completely positive evaluation')

\section{Evaluation of the national economic situation in the last year}

Scale from 0 ('really bad') to 10 ('really well') 